Western Washington University

Western CEDAR

\title{
Why Politicians Like Electoral Institutions: Self- interest, Values, or Ideology?
}

Todd Donovan

Western Washington University, todd.donovan@wwu.edu

Shaun Bowler

Jeffrey A. Karp

Follow this and additional works at: https://cedar.wwu.edu/politicalscience_facpubs

Part of the Political Science Commons

\section{Recommended Citation}

Donovan, Todd; Bowler, Shaun; and Karp, Jeffrey A., "Why Politicians Like Electoral Institutions: Self-interest, Values, or Ideology?" (2006). Political Science Faculty Publications. 17.

https://cedar.wwu.edu/politicalscience_facpubs/17 


\section{CAMBRIDGE UNIVERSITY PRESS}

\section{Southern Political Science Association}

Why Politicians Like Electoral Institutions: Self-Interest, Values, or Ideology? Author(s): Shaun Bowler, Todd Donovan and Jeffrey A. Karp

Source: The Journal of Politics, Vol. 68, No. 2 (May, 2006), pp. 434-446

Published by: Cambridge University Press on behalf of the Southern Political Science Association Stable URL: http://www.jstor.org/stable/4639852

Accessed: 23/10/2014 17:20

Your use of the JSTOR archive indicates your acceptance of the Terms \& Conditions of Use, available at http://www.jstor.org/page/info/about/policies/terms.jsp

JSTOR is a not-for-profit service that helps scholars, researchers, and students discover, use, and build upon a wide range of content in a trusted digital archive. We use information technology and tools to increase productivity and facilitate new forms of scholarship. For more information about JSTOR, please contact support@jstor.org. 


\title{
Why Politicians Like Electoral Institutions: Self-Interest, Values, or Ideology?
}

\author{
Shaun Bowler University of California, Riverside \\ Todd Donovan Western Washington University \\ Jeffrey A. Karp Texas Tech University and University of Twente, the Netherlands
}

\begin{abstract}
We examine whether MPs and candidates for parliament are motivated by electoral self-interest, values, ideology, or all of these when evaluating proposals for changing electoral institutions. Using survey data from four countries (Australia, Germany, the Netherlands, and New Zealand), we find that candidates who won election are less supportive of proposals to change institutions, while those who lost elections are more supportive of institutional changes. Winning candidates share preferences for institutions that are independent of whether they are affiliated with a governing or opposition party. This self-interest effect is attenuated by ideology and attitudes about democracy. Pure self-interest, then, is an incomplete explanation for politicians' attitudes towards electoral institutions. We discuss how these findings are related to the static nature of political institutions.
\end{abstract}

$\longrightarrow$ hange in election rules is a relatively rare event in established democracies (Dunleavy and Margetts 1995; Lijphart 1992). One central assumption of theories of electoral system change is that those in power only change rules strategically, in order to protect their self-interest (Benoit 2004; Boix 1999; Grofman 1990; Rokkan 1970; in contrast see Andrews and Jackman 2005; Blais and Massicotte 1997). Change in electoral institutions is relatively rare because it is the winners under status quo rules, as Cox notes $(1997,18)$, who must find it in their interest to alter the rules they were elected under. Institutions are "sticky" because politicians are assumed to want durable rules that allow them to maintain control over their fate (Przeworski 1991; Shepsle 2001, 321).

This key assumption about self-interest structuring politicians' preferences for institutions, however, has not been tested with direct evidence from politicians themselves. In this paper we examine politicians' attitudes about changing electoral institutions in four established democracies. We demonstrate that rational self-interest is a major feature of elite attitudes about electoral institutions, but we also establish that attitudes about democracy and political ideology also have a role to play. We conclude that once in power, politicians may develop a great deal of positive affect for current institutions and a resistance to change; regardless of whether or not their party is part of government or opposition. These findings shed some light on why electoral institutions are typically so resilient.

\section{Politicians' Evaluations of Electoral Institutions}

We can understand politicians' attitudes and opinions towards electoral institutions in terms of two broad theoretical frameworks. Although these frameworks are not necessarily mutually exclusive, they offer rival explanations and imply different understandings of the relationship between politicians and the institutions under which they work.

\section{Winning, Losing, and Self-Interested Views of Institutions}

Electoral systems often have clear-cut effects in determining who is elected and who has influence over the political agenda. Put differently, electoral rules determine who winners and losers are-as such alterations in these rules have effects that politicians are keen to understand (Tsebelis 1990, 104). After a system has been in use for some time, it is generally apparent to 
those playing the electoral game how the rules define who the winners and losers may be. One of the major concerns facing politicians, then, will be concerns for winning and, in particular, losing (Anderson and Guillory 1997). Losers, wanting to become winners, may support rule changes that they anticipate may make them winners in the electoral arena, ${ }_{1}^{1}$ or give them more influence over policymaking (Miller 1983; Riker 1980, 445). Meanwhile incumbents may resist changing rules given that they are familiar with the rules that placed them in office and given risk aversion associated with the uncertainty inherent in new electoral institutions (Andrews and Jackman 2005; Shvetsova 2003). If incumbent (winners') self-interest structures preferences for electoral institutions, change is likely only when a sufficient number of incumbents expect to gain more influence under new rules (Benoit 2004) or when opposition forces reach sufficient density to force change upon incumbents (Norris 1995).

The argument that politicians' views of electoral institutions will be strongly colored by self-interest is hardly a surprising one. It is, for example, consistent with several previous case studies of politicians in a wide variety of settings and time periods (e.g., Angus 1952; Bawn 1993; Boix 1999; Bowler, Donovan, and Karp 2002; Geddes 1996; Gunther 1989; Rokkan 1970). We suggest that there are two ways in which self-interested politicians may perceive winning and losing: their own personal win or loss and that of their party. In general we expect that the sense of personal loss will be most keenly felt by politicians and that they will be most responsive to that loss. Therefore, we expect that losing candidates will be most supportive of change, all other things being equal.

It is also possible that there is a "party" interest that is distinct from a candidate's personal interest. For example, winners in opposition parties may generally be supportive of changes that give the opposition greater influence. Small parties are favored by proportional rules, so we might expect winners from smaller parties to favor changes that might make their election system more proportional. Katz and Mair (1995) propose another version of party interest: incumbents in and out of government may have shared interests and may form cartels to limit electoral competition.

${ }^{1}$ There are many examples among mass publics and politicians, including debate over proportional representation $(\mathrm{PR})$ in the United Kingdom, support for PR in New Zealand, electoral system reform in Japan and Italy and mass support for term limits in the United States.
To claim that politicians view institutions in selfinterested terms may seem so straightforward that some might find it a bit of a "straw-man." It is important to note that our stress on winning and losing puts limitations on what we mean by self-interest. The version of self-interest we advance here emphasizes incumbents' concerns for avoiding loss rather than making gains, and, second, it assumes politiciansparticularly losers seeking to be winners-may not understand the long term consequences of changes they consider.

There is a different model of how self-interest drives politician's views of electoral change that assumes politicians may work to maximize future gains via rules changes (e.g., Angus 1952; Benoit 2004). This model may fit cases where electoral reforms can be designed to benefit incumbents over the long term (i.e., restrictive ballot access rules; districting procedures that create safer seats). However we are interested in how politicians reason about electoral reforms that might alter incumbent power (i.e., term limits and initiative use) or create uncertainty about election outcomes (i.e., compulsory voting). Electoral reforms, furthermore, are not as common as one might expect given a model that assumes gainmaximizing, forward-looking incumbent behavior as the definition of self-interest. As Benoit notes, electoral change is not costless. Such models of selfinterest may overstate how much is known about electoral laws and their effects: reforms bring risks of unintended consequences.

Despite all their incentives to understand electoral systems, then, politicians may have an imperfect understanding of them, possibly dampening the effect of prospective self-interest on preferences for institutions. Uncertainty and risk aversion are therefore likely to be major factors that may make it difficult for politicians to rely upon self-interest to evaluate proposals for changing electoral institutions. Of particular importance is uncertainty (Andrews and Jackman 2005; Shvetsova 2003). Even if politicians do become aware of the consequences of, say, term limits or a shift away from proportionality, it may take them a while to understand the consequences of how the change affects a party's prospects for winning or losing. As Birch et al. note in their discussion of changes in Eastern Europe, "actors had some understanding of the general consequences of electoral systems vis-à-vis party development. Yet they were often mistaken when it came to the specifics... and this hampered their ability to craft electoral institutions to suit their immediate political ends" (2003, 170; emphasis in original). 
Although there are different ways of defining and modeling self-interest, the version we have advanced here-that winners seek to protect the status quo-is consistent with these limitations of information and costliness. Politicians may well have concerns for gain maximization over some discounted time horizon but these concerns will—by hypothesis—only come after the concerns about shorter-term losses are addressed.

\section{Values, Ideology, and Attitudes about Democracy}

There are several plausible reasons for expecting that explanations of politicians' views of institutions are not wholly grounded in self-interest: even a version of self-interest that takes account of uncertainty and risk aversion. An alternative theoretical framework challenges the primacy of self-interest as an explanation of politicians' preferences for electoral institutions. Politicians' views about democratic processes may also mute the potential effect of electoral self-interest. Opinions of politicians across a range of issues, including institutional issues, are likely to be shaped by values. A study of election rules in 166 nations concluded that selection of an electoral system is not merely the product of partisan interest, "but is also strongly influenced by ideas about what is good or just" (Blais and Massicotte 1997, 107; see also Rahat 2004; Sakamoto 1999). Concerns about democratic process inform views of political institutions, even at a mass level (Hibbing and Theiss-Morse 2002; Tyler 1990). We know, furthermore, that elites have views that are strongly constrained or shaped by ideology (e.g., Converse 1964; Peffley and Hurwitz 1985). Politicians may thus have commitments to values that shape their views of how the electoral process should be structured; these values may well constrain selfinterested concerns about whether they win or lose under different electoral arrangements.

A narrow self-interest model of how politicians reason about electoral arrangements would suggest a concern for outcomes over process: here we suggest that ideas about democracy may make process concerns more relevant. ${ }^{2}$ Attitudes about the proper role of mass participatory democracy, for example, may well produce a commitment to, or at least positive affect for, specific types of electoral arrangements

\footnotetext{
${ }^{2}$ We should stress that this is a different kind of concern for nonself-interested explanations than that seen in the discussion in the coalition literature of policy-seeking versus office-seeking motivations of politicians (Muller and Strom 1999). The kinds of attitudes we are discussing are those which shape attitudes towards the political process more than specific policy outcomes.
}

that do not necessarily advance a politicians' own electoral prospects or ability to control policy outcomes. Process-oriented concerns may thus figure at least as prominently as self-interest. Consider the case of major campaign finance reform in the United States. Despite the fact that some observers predicted that the McCain-Feingold legislation would place Democrats at a disadvantage relative to Republicans in their efforts to finance future elections, party affiliation was an imperfect predictor of floor votes on the legislation. ${ }^{3}$ Numerous Democrats supported the proposal in the name of improving public perceptions of the political process, while prominent Republicans opposed it on the grounds that the regulations inhibited free speech.

As another example that democratic values may shape politicians' preferences for electoral institutions, consider Britain's Liberal Democrats' justification of their support for proportional representation:

Governments likely to result from the introduction of proportional representation would be more reliant on persuasion and debate, rather than sheer weight of numbers, to guide through legislation. (Liberal Democrats 2000,16 )

That is, normative democratic virtues of deliberative democracy and participation may be promoted through electoral reform. Of course politicians routinely clothe naked self-interest in a fig-leaf of noble words. In the case of the Liberal Democrats, electoral reform not only helps realize their stated democratic virtues, but we should remember that it would also likely give them many more seats. However, rather than dismiss such comments as a rhetorical device disguising self-interested intentions we could, equally, see them as a sincere statement of principle. A commitment to the principle of inclusion in the political process could lead a politician from a "big" party to have a commitment to proportional representation, even though she (or her party) may otherwise benefit from majoritarianism. The example from the Liberal Democrats may illustrate that politicians might couch talk about institutions in noble terms, rather than advocate that a new electoral rule might make them a winner. Yet it may well be that such comments are true indications of the way politicians really think about institutions. Similarly, politicians who are generally dissatisfied with how democracy is working in

${ }^{3}$ McCain-Feingold, or the Bi-Partisan Campaign Finance Reform Act (BCRA) limited "soft money" contributions to the parties. Under President Clinton, Democrats kept pace with Republican advantages in "hard" contributions by raising soft money. BCRA may shift fundraising efforts to "hard" contributions. 
their country may be more likely to support a wide range of rule changes that might offer them perception of an improvement over status quo arrangements.

\section{Hypotheses}

Before testing specific hypotheses about the relationship between attitudes about democracy, self-interest, and politicians' preferences for institutions, we must address some matters of definition. Specifically, what do we mean by a politician's electoral self-interest, and how is it associated with winning and losing? At the mass level, definitions have focused on whether voters identify with the party that wins or loses control of government (e.g., Anderson and Guillory 1997). As for elites, there may be more than one way of defining a win or a loss. As noted above, a politician's own party may win or lose governing power while, independent of this, politicians themselves may win or lose their own election. A candidate's perspective as a winner or loser is defined here by these two variables and can be thought of in terms of a simple $2 \times 2$ classification; pairing a candidate's personal success or failure with her party's success or failure. That is, there are candidates who win a seat and their party ends up in government; those who win a seat but their party is in opposition; those who lose but their party is in government; and those who lose while their party is in opposition.

Self-interest provides expectations about the preferences of winners who are members of the government. We expect them to be most supportive of current electoral arrangements and most resistant to institutional change. Conversely, those who personally lose an election and whose party is out of power are expected to be least sympathetic to the status quo and most supportive of institutional changes. Politicians who make it to the legislature but remain in the opposition as well as those who lose their own election but whose party wins office should fall somewhere between the two extremes. The degree of affect towards or attachment to current electoral institutions (e.g., evaluations of how well elections work to make MPs reflect voters, and satisfaction with how democracy works in their nation) is likely to be cooler among candidates in this middle group than among those in the personal win + party win category, but warmer than among those in the personal loss + party loss category.

Self-interest also leads us to expect an additional effect, independent of the politician's status as a winner or loser. Candidates of smaller parties are unlikely to control government-even under proportional representation (PR) their best hope is to serve as the junior member of a coalition. Small-party candidates may thus be more likely to embrace reforms that alter the influence of incumbent legislators (term limits) and rules that give outsiders more influence over the public agenda (direct democracy).

Alternatives to the self-interest explanation lead us to expect that attitudes and values about proper democratic arrangements may define politicians' preferences for institutions. In particular, their attitudes about the desirability of democratic participation, or their position on the left-right dimension, may affect attitudes towards current electoral institutions and support for changing electoral arrangements. Democratic values, particularly those associated with the materialist/post-materialist dimension (Dalton 2002, 83; Inglehart 1977), are expected to correspond with preferences for new electoral rules that provide for greater, direct citizen influence over government. Post-materialists politicians who value political expression and value giving people more say in government decisions may be more supportive of reforms, even if these reforms weaken their own control of the political agenda. Preferences for various democratic institutions may also be affected by attitudes associated with political ideology. Members of right-of-center parties, for example, may subscribe to classic, small " $c$ " conservatism and be reluctant to support changes of any kind and, thus, express more affect for the current institutional arrangements. Finally, attitudes about specific institutional elements of election systems may not be independent of general sentiments about the nation's political system, such as satisfaction with how democracy is currently working.

\section{Data, Models and Results}

Data employed to test these hypotheses come from surveys of national level politicians in Australia, Germany, the Netherlands, and New Zealand, conducted between 1999 and 2002. These surveys of candidates and MPs were conducted at the time of general elections in each country. The response rates for these surveys range from $51 \%$ to $58 \%$. An online appendix with details on samples, question wording, response rates, and alternative models specifications may be found at http://www.journalofpolitics.org. Each of these nations are established democracies, with basic election rules in Australia, Germany, and the Netherlands largely stable for several decades. 
Nonetheless, electoral reform issues are recurring topics of debate in each nation. Expanded use of direct democracy has received substantial discussion in each nation in the past decade (Dalton, Burklin, and Drummond 2001; Karp and Aimer 2002; Williams and Chin 2000), as has, to a lesser extent, compulsory voting (Mackerras and McAllister 1999), which is used in Australia and was used in the Netherlands until 1970. New Zealand, furthermore, underwent a change from winner-take-all to a mixed-member proportional system in 1996. The Dutch have also been debating changing from PR to a mixed system.

There are two main methodological virtues to this cross-national approach. First, data from multiple nations allow us to assess the effects of incumbent selfinterest across different parties and different electoral contexts. Second, the multiple country approach helps to untangle the effects of values and ideology from self-interest. With elite opinion data from just one nation it would be difficult to say that opinion of members of the government reflected the fact that they were in government, or that government included right-of-center parties, or a post-materialist party. Our four cases, however, give us variation in the ideological composition of government with two right-of-center governments (Netherlands and Australia) and two left-of-center ones (Germany and New Zealand). This allows us to distinguish the effects of whether a candidate won or lost an election from the effects of values and ideology.

We should address whether politicians may have incentives to offer publicly acceptable survey responses designed to mask their self-interested views of electoral reform. First, it is important to note that the surveys were voluntary, conducted through wellregarded academic institutions in each nation, and that respondents were assured confidentiality. Second, respondents were offered the "don't know" response option. Each of these factors decreases the likelihood that respondents may feel pressured to offer publicly acceptable rhetoric as responses. Third, questions used in the analysis here were scattered throughout a long survey instrument. This makes it difficult for respondents to ascertain our research questions and clouds their ability to structure responses to affect the results. Fourth, there is little need for respondents to actively lie. The questions we ask have been subjects of open discussion and debate within each of these countries for years. Finally, it is hard to think of the incentives that would prompt respondents to not only actively lie but to do so in a way that would bias our results since it would require different incentives for winners and for losers.
The survey instruments included a battery of items measuring attitudes toward each nation's current electoral system as well as questions about specific electoral reform proposals (see online appendix for question wording). We estimate models for five dependent variables; two that measure affect towards the respondent's current electoral system and three that measure support for specific changes in existing electoral arrangements. Measures of affect toward status quo electoral arrangements are: (1) satisfaction with how democracy is working in the nation and (2) opinion about whether the nation's elections accurately reflect the views of voters. All responses have been recoded to reflect dichotomous choices, where 1 $=$ a positive evaluation on each item, and 0 a negative one. Clearly, our expectation is that the biggest winners under current rules-winning candidates who are members of government-are most likely to express positive affect towards current political arrangements.

Our three measures of support for institutional change asked respondents: (1) if term limits on legislators should be adopted, (2) if they support use of referendum and initiative, and (3) if the nation's existing rules regarding compulsory voting should be changed. ${ }^{4}$ Responses to these items are also dichotomized, so that positive responses equal 1. Each of these questions presents an electoral arrangement that alters the rules under which incumbents were elected, and/or alters an incumbent's ability to control the policy agenda. Conversely, each proposal may be seen as creating new opportunities for politicians who lose elections. In general then, we expect that winners will be opposed to these proposals. It is important to note that some of these proposals for change have majority or near majority levels of support among the candidates we surveyed, and that these rules-in various forms-could be changed by statute or constitutional amendment processes that are less burdensome than the process for amending the U.S. Constitution. ${ }^{5}$

As Table 1 shows, bivariate results are consistent with the self-interest hypothesis: winners are most

\footnotetext{
${ }^{4}$ This means that the question about compulsory voting in Australia is coded such that repealing compulsory voting represents a change from the status quo.

${ }^{5}$ There is no formal constitution in New Zealand. In the Netherlands, constitutional change requires a two-thirds majority of both houses of parliament. Consensus politics there has provided for large governing coalitions. In Australia the constitution is amended by referendum-but major electoral reforms such as compulsory voting were adopted by majorities in parliament. Congress can adopt PR for the U.S. House by statute.
} 


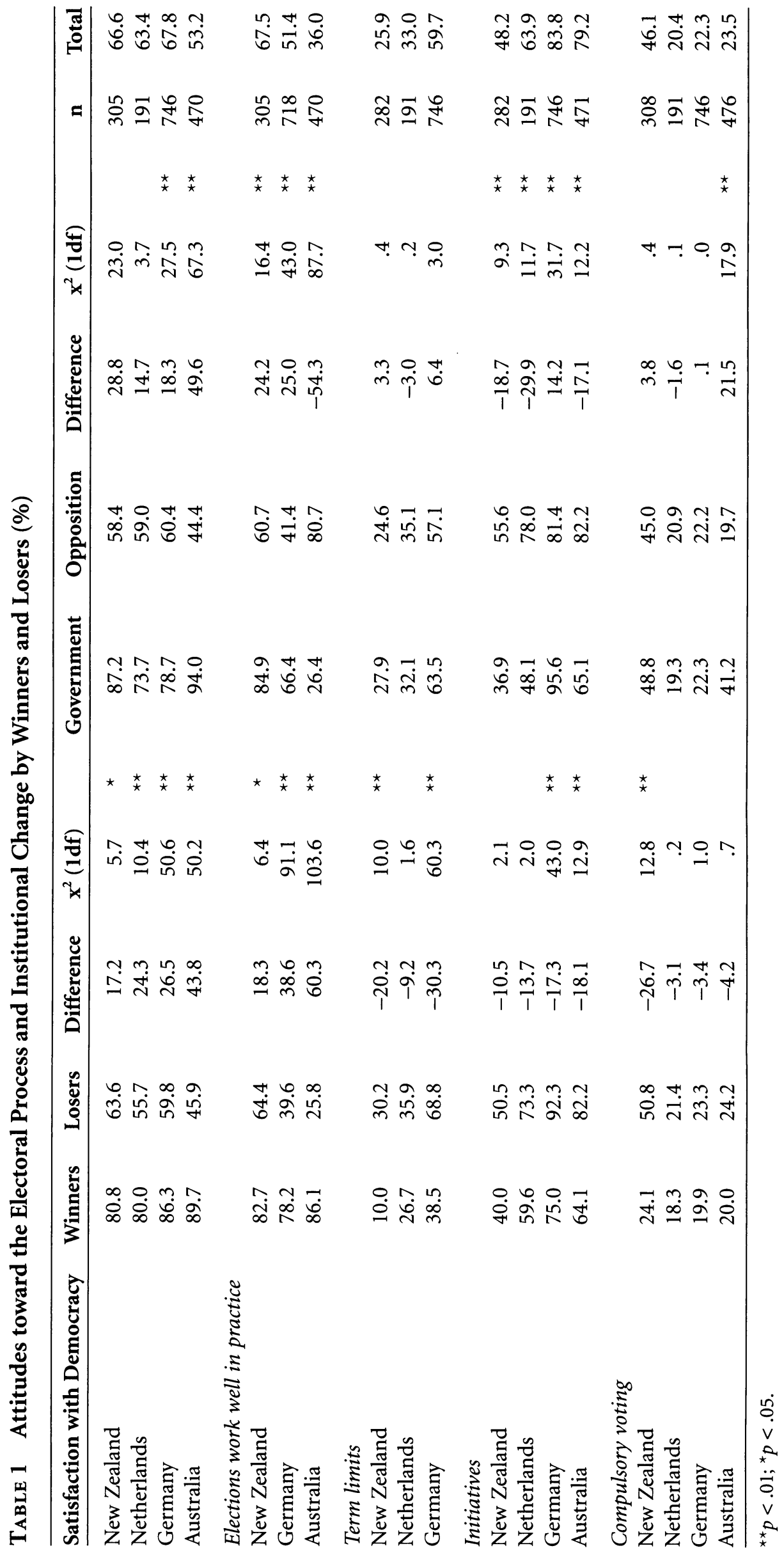


supportive of existing political arrangements. The significance of differences between groups is represented by chi-square values. ${ }^{6}$ In Australia, elected MPs were twice as likely as losing candidates to be satisfied with democracy. In New Zealand, where the difference is the smallest, there was still a significant satisfaction gap of about $17 \%$ between winners (incumbents) and candidates who lost. Similar differences in satisfaction were found between members of the government and opposition parties. The Netherlands uses the most proportional system of representation of these four nations and is the most consensual form of democracy in our sample (see Lijphart 1999). We find the difference between the government and the opposition was the smallest on most items among Dutch respondents.

Clear winner-loser differences exist on the items measuring attitudes toward institutional change. Overall, candidates in all four countries were generally receptive to initiative and referenda use, although they were, with the exception of Germany, generally cool to the idea of imposing term limits on members of parliament. Nevertheless, winners by and large were much less likely to support these proposed changes than losers. As for compulsory voting, the results are generally consistent with our expectations, though the gap between winners and losers was rather small in Australia, Germany, and the Netherlands. In Australia, which is the only country in the sample that has compulsory voting, winners were slightly less likely to want to change the system than the losers. However, there was a substantial gap in Australia between the government and the opposition on this issue, with the Liberal/National government coalition being more likely to want to change the system than opposition candidates. In New Zealand, losing candidates were twice as likely to want to impose compulsory voting as the winning candidates.

Multivariate analysis can establish if there are independent, additive effects of our markers of incumbent self-interest: winning office and being a member of a party in government. It can also establish if these markers of incumbent self-interest predict attitudes about electoral institutions when we control for values and ideology. Our multivariate models of politicians' preferences include a dummy variable representing respondents who were elected (winners), and a dummy variable representing respondents who were affiliated with a party in government. Respon-

${ }^{6}$ There are four cells for each significance test. For example, winners who are satisfied with democracy, winners who are dissatisfied, losers who are satisfied, losers who are dissatisfied. dents affiliated with small parties are also represented by a unique dummy variable, as they may have distinctive attitudes about PR elections. Our measure of post-materialist values is composed of responses to two standard questions. Respondents who prioritized "giving people more say" over "maintaining order" and who also ranked "protecting freedom of speech" over "fighting rising prices" were coded 1; those who gave top priority to just one of these post-materialist values were coded 0 ; while those who gave top priority to prices and maintaining order were coded -1 . Political ideology is represented by the respondent's self-placement on a continuum ranging from 0 (left) to 10 (right). ${ }^{7}$ We also account for the politician's assessment of how democracy is working in their nation in our estimates of preferences for electoral institutions.

The data have been pooled and dummy variables for respondents from New Zealand, the Netherlands, and Australia (leaving Germany as the reference category) are included in the model to account for unspecified nation-specific effects. ${ }^{8}$ As evident in Table 1, one of our questions about affect toward the electoral system and one about institutional change (term limits) were absent from the Australian survey. These cases are lost in the pooled models; however, nation-specific estimations produced results (provided to reviewers and available online) that are substantively similar to those reported here. Logistic regression is used to estimate the results since all the dependent variables are coded as dichotomous choices.

The results of our logistic regression estimates are reported in Table 2 and Table 3. We find consistent effects of self-interest (noted as winner and government party) in each estimation. Winning candidates' attitudes about their electoral institutions were distinctive, moreover, regardless of whether a winner's party was in office, and regardless of left-right ideology and post-materialist values. In terms of their perspective on current electoral arrangements (Table 2), winners are more likely to be satisfied with democracy and are more likely to believe that elections work well in practice. We also find a significant, independent effect of affiliation with a governing party. Data in Table 2 demonstrate that candidates from these parties, whether winners or losers, are significantly

\footnotetext{
${ }^{7}$ We estimated the models with and without the ideology and Postmaterialism. Inclusion or omission of these variables do not affect the results reported.

${ }^{8}$ Nation specific estimates are available in the online appendix found at: http://www.journalofpolitics.org.
} 
TABLE 2 Politicians' General Affect Towards their Electoral System

\begin{tabular}{|c|c|c|c|c|}
\hline & \multicolumn{2}{|c|}{$\begin{array}{c}\text { Satisfaction with } \\
\text { Democracy } \\
\end{array}$} & \multicolumn{2}{|c|}{$\begin{array}{c}\text { Elections Work } \\
\text { Well }\end{array}$} \\
\hline & Estimate & SE & Estimate & SE \\
\hline Winner & $.43^{* *}$ & $(.18)$ & $.98^{\star * *}$ & $(.21)$ \\
\hline Government party & $.71^{* * *}$ & $(.14)$ & $1.00^{* * *}$ & $(.16)$ \\
\hline Small party & $-1.07^{* * *}$ & $(.15)$ & $-1.23^{\star * *}$ & (.19) \\
\hline Female & .19 & $(.13)$ & $.35^{\star \star}$ & $(.16)$ \\
\hline Age & $-.01^{\star}$ & $(.01)$ & .00 & $(.01)$ \\
\hline Postmaterialism & $-.49^{\star * *}$ & $(.11)$ & $-.24^{*}$ & $(.14)$ \\
\hline L/R Ideology & $1.29^{* * *}$ & $(.27)$ & $.96^{* * *}$ & $(.34)$ \\
\hline New Zealand & $-.32^{\star}$ & $(.16)$ & - & - \\
\hline Netherlands & -.31 & $(.20)$ & - & - \\
\hline Australia & $-.43^{* * *}$ & $(.24)$ & $-.45^{\star *}$ & $(.17)$ \\
\hline Constant & $1.21^{* * *}$ & $(.29)$ & -.05 & $(.38)$ \\
\hline Pseudo R2 & .15 & & .23 & \\
\hline Observations & 1,568 & & 1,112 & \\
\hline
\end{tabular}

${ }^{\star * *} p<.01 ;{ }^{* *} p<.05 ;{ }^{\star} p<.10$.

Note: Logistic regression estimates. Standard errors are in parentheses.

more complacent about their nation's existing electoral arrangements. Likewise, candidates from governing parties, whether winners or losers, have more positive attitudes about current political arrangements. Respondents from small parties are less supportive of current political arrangements. ${ }^{9}$

As for politicians' support for institutional changes (Table 3), winners (from parties in or out of government) are significantly less likely than losers to support any of the proposed reforms. There was, however, no increased likelihood of opposing change due to affiliation with a governing party. This result is consistent with Katz and Mair's (1995) cartel party thesis. Winners from government and opposition parties appear quite similar in their hesitance to endorse electoral system change (also see Table 4). We do find evidence that partisan self-interest motivated members of small parties, independent of whether they won or lost their elections or their party was in government. Respondents from small parties are more supportive of term limits and direct democracy. For politicians from large parties, their self-interested perspective on electoral institutions thus seems to have more to do with their personal electoral success, rather than with their party's status in government. All of this suggests that winners from larger parties may share a

${ }^{9}$ Further analysis shows that small party candidates were more likely to think that their nation's PR system was fair. cartel-like consensus on their preferences for electoral institutions, regardless of the effect of winning or losing control of government.

Despite the consistent effects, self-interest does not provide a complete explanation of politicians' preferences for these changes in electoral institutions. Candidates who are most satisfied about how democracy is working, for example, are consistently less interested in altering existing arrangements. Postmaterialist values and political ideology also affect attitudes about institutions. ${ }^{10}$ Candidates on the right are more optimistic about status quo political arrangements ${ }^{11}$ and are also significantly less supportive of term limits and direct democracy. Contrary to our expectation that conservatives would oppose change generally, we find they are more supportive of changing rules for compulsory voting, although nation-specific models demonstrate this relationship is exclusive to Australia. We also find that post-materialist respondents are consistently less sanguine about existing political arrangements. Their dissatisfaction with existing electoral practices does not appear to have translated into support for new electoral arrangements in the pooled analysis. Post-materialists in Germany and Australia, however, are more supportive of direct democracy, and German post-materialists are more supportive of term limits.

To ease the interpretation of the results, we translated the logit coefficients estimated from our models into predicted probabilities for those variables where our models predict statistically significant differences between key groups of candidates. These illustrate the effect a change in one of our independent variables has on increasing the probability that a respondent gave a positive reply on our dependent variables, with the effects of other independent variables held constant.

Table 4 presents the gap in attitudes and the gap in support for change between winners and losers, grouped by whether or not the candidate was from a party that ended up in government. Winners from government parties are much more sanguine about existing electoral arrangements than winners from opposition parties, and opposition party losers are least optimistic about current electoral arrangements. Government party winners have a .81 probability of saying they are satisfied with democracy, and a .77 probability of saying that elections work well at

\footnotetext{
${ }^{10}$ These two ordinal items are modestly correlated (-.31); right of center candidates are less post-materialistic.

${ }^{11}$ This result is largely driven by Germany.
} 
TABLE 3 Politicians' Attitudes Toward Institutional Change

\begin{tabular}{|c|c|c|c|c|c|c|}
\hline & \multicolumn{2}{|c|}{ Adopt Term Limits } & \multicolumn{2}{|c|}{$\begin{array}{l}\text { Use Referendums } \\
\text { and \& Initiatives }\end{array}$} & \multicolumn{2}{|c|}{$\begin{array}{c}\text { Change Laws on } \\
\text { Compulsory Voting }\end{array}$} \\
\hline & Estimate & SE & Estimate & SE & Estimate & SE \\
\hline Winner & $-.76^{\star \star \star}$ & $(.18)$ & $-.30^{\star}$ & $(.16)$ & $-.64^{\star \star \star}$ & $(.19)$ \\
\hline Government party & $.33^{* *}$ & $(.15)$ & .10 & $(.14)$ & .23 & $(.15)$ \\
\hline Small party & $.66^{\star * *}$ & $(.17)$ & $.83^{\star * \star}$ & $(.16)$ & $-.56^{\star \star}$ & $(.18)$ \\
\hline Female & $.51^{\star \star \star}$ & $(.15)$ & -.05 & $(.14)$ & $-.27^{\star}$ & $(.16)$ \\
\hline Age & $.02^{* *}$ & $(.01)$ & .00 & $(.01)$ & $.01^{\star *}$ & $(.00)$ \\
\hline Satisfaction with democracy & $-.59^{\star * \star}$ & $(.15)$ & -.19 & $(.15)$ & $-.56^{\star \star \star}$ & $(.16)$ \\
\hline Post-materialism & .05 & $(.14)$ & .13 & $(.13)$ & -.21 & $(.13)$ \\
\hline L/R Ideology & $-1.08^{\star * *}$ & $(.35)$ & $-1.42^{* * *}$ & $(.30)$ & $.59^{*}$ & $(.32)$ \\
\hline New Zealand & $-1.86^{* * *}$ & $(.19)$ & $-1.87^{\star * *}$ & $(.18)$ & - & - \\
\hline Netherlands & $-.96^{* * *}$ & $(.20)$ & $-.78^{\star * *}$ & $(.21)$ & -.09 & $(.21)$ \\
\hline Australia & - & - & $-.35^{\star *}$ & $(.17)$ & -.02 & $(.28)$ \\
\hline Constant & .08 & $(.38)$ & $1.85^{\star \star \star}$ & $(.37)$ & $-1.08^{\star *}$ & $(.36)$ \\
\hline Pseudo R2 & .17 & & .14 & & .03 & \\
\hline Observations & 1,126 & & 1,567 & & 1,302 & \\
\hline
\end{tabular}

${ }^{* *} p<.01 ;{ }^{* *} p<.05 ;{ }^{*} p<.10$.

Note: Logistic regression coefficients. Standard errors are in parentheses.

TABle 4 Predicted Probabilities of Support; Winners and Losers by Government Party Status

\begin{tabular}{|c|c|c|c|c|c|c|c|c|c|c|}
\hline & \multicolumn{4}{|c|}{ Opposition Party } & \multirow[b]{3}{*}{$\Delta$} & \multicolumn{4}{|c|}{ Government Party } & \\
\hline & \multicolumn{2}{|c|}{ Losers } & \multicolumn{2}{|c|}{ Winners } & & \multicolumn{2}{|c|}{ Losers } & \multicolumn{2}{|c|}{ Winners } & \\
\hline & prob. & $\begin{array}{c}\text { Conf. } \\
\text { Int. }(+/-)\end{array}$ & prob. & $\begin{array}{c}\text { Conf. } \\
\text { Int. }(+/-)\end{array}$ & & prob. & $\begin{array}{c}\text { Conf. } \\
\text { Int. }(+/-)\end{array}$ & prob. & $\begin{array}{l}\text { Conf. } \\
\text { Int. }(+/)\end{array}$ & $\Delta$ \\
\hline $\begin{array}{l}\text { Satisfaction with } \\
\text { democracy }\end{array}$ & .58 & $(.04)$ & .67 & $(.06)$ & .09 & .73 & $(.05)$ & .81 & $(.05)$ & .08 \\
\hline $\begin{array}{l}\text { Elections work well } \\
\text { in practice }\end{array}$ & .31 & $(.04)$ & .55 & $(.06)$ & .24 & .56 & $(.07)$ & .77 & $(.07)$ & .21 \\
\hline Term limits & .49 & $(.05)$ & .31 & $(.07)$ & -.18 & .57 & $(.06)$ & .38 & $(.08)$ & -.19 \\
\hline Initiative & .79 & $(.03)$ & .74 & $(.06)$ & -.05 & .81 & $(.04)$ & .76 & $(.06)$ & -.05 \\
\hline Compulsory voting & .24 & $(.03)$ & .14 & $(.04)$ & -.10 & .28 & $(.05)$ & .17 & $(.05)$ & -.11 \\
\hline
\end{tabular}

Note: Estimates derived from Tables 2 and 3 holding all other variables constant at their mean.

Confidence intervals are 95 and calculated by delta method (Xu and Long forthcoming).

reflecting the views of voters. In contrast, winning candidates from opposition parties have a .67 probability of being satisfied with democracy and a .55 probability of saying that elections worked well. Despite substantial differences between government and opposition winners' attitudes about existing electoral arrangements, these winning candidates have fairly similar views about changing institutions. Winners in government are predicted to have just a .38 probability of supporting term limits, similar to the probability of support among opposition party winners (.31). Governing party winners are predicted to have just a .17 probability of changing rules about compulsory voting, similar to the probability of support among opposition winners (.14).

Table 5 reports the predicted probabilities of the independent effects of ideology and post-materialist values. Again, we find that these variables have substantial effects on politicians' evaluations of existing elections and on the probability of their supporting electoral reforms. Post-materialists values are associated with nearly a .21 decrease in the probability that a candidate is satisfied with how democracy is working, and a .12 decrease in the probability that a respondent thinks elections work well reflecting voters' views. The effects of being on the farthest ends 
TABle 5 Predicted Probabilities of Support; by Post-Materialism and Ideology

\begin{tabular}{|c|c|c|c|c|c|c|c|c|c|c|}
\hline & \multicolumn{2}{|c|}{ Materialist } & \multicolumn{2}{|c|}{ Post-Materialist } & \multirow[b]{2}{*}{$\Delta$} & \multicolumn{2}{|c|}{ Left } & \multicolumn{2}{|c|}{ Right } & \multirow[b]{2}{*}{$\Delta$} \\
\hline & prob. & $\begin{array}{c}\text { Conf. } \\
\text { Int. }(+/-) \\
\end{array}$ & prob. & $\begin{array}{c}\text { Conf. } \\
\text { Int. }(+/-)\end{array}$ & & prob. & $\begin{array}{c}\text { Conf. } \\
\text { Int. }(+/-) \\
\end{array}$ & prob. & $\begin{array}{c}\text { Conf. } \\
\text { Int. }(+/-)\end{array}$ & \\
\hline $\begin{array}{l}\text { Satisfaction with } \\
\text { democracy }\end{array}$ & .77 & $(.05)$ & .57 & $(.05)$ & -.21 & .53 & $(.06)$ & .80 & $(.05)$ & .27 \\
\hline $\begin{array}{l}\text { Elections work well } \\
\text { in practice }\end{array}$ & .52 & $(.09)$ & .40 & $(.06)$ & -.12 & .35 & $(.07)$ & .59 & $(.10)$ & .23 \\
\hline Term limits & .45 & $(.09)$ & .48 & $(.07)$ & .03 & .57 & $(.07)$ & .31 & $(.09)$ & -.26 \\
\hline Initiative & .75 & $(.06)$ & .80 & $(.04)$ & .05 & .87 & $(.03)$ & .61 & $(.09)$ & -.26 \\
\hline Compulsory voting & .27 & $(.07)$ & .19 & $(.04)$ & -.07 & .18 & $(.04)$ & .29 & $(.08)$ & .10 \\
\hline
\end{tabular}

Note: Estimates derived from Tables 2 and 3 holding all other variables constant at their mean.

Confidence intervals are 95 and calculated by delta method (Xu and Long forthcoming).

of the ideological spectrum are quite striking; with conservatives generally more opposed to change. Other things being held equal, a candidate on the far left has a .87 predicted probability of supporting direct democracy, while a candidate on the far right is predicted to have a .61 probability of this. The left-right gap in support for term limits is similar. Left-right differences in support for compulsory voting run in the opposite direction, but are nearly the same magnitude.

Overall, our results demonstrate that politicians' self-interest operates, quite often, as theory predicts. Compared to values and ideology, the expected effects of electoral self-interest on preferences for institutions are readily understood from prior theory. Although we also find effects of values and ideology, the effects of ideology in particular are not as easy to explain. We do not know, a priori, why conservatives in these nations should be more supportive of changing rules on compulsory voting, nor what causes leftists to favor term limits. ${ }^{12}$ Nonetheless, it is important to note that there are sizeable independent effects of values and ideology and that the substantive magnitude of these effects rivals the effect of electoral self-interest. The difference in probability of support for term limits, for example, is greater between far left and far right respondents (a .26 difference in probability of support) than it is between governing party winners and losing candidates of opposition parties (a .11 difference). Likewise, the difference in the probability of supporting use of initiative and referendum between

${ }^{12}$ The latter effect may likely be driven by Australian conservatives in the Liberal/National coalition who are opposed to the use of compulsory voting in that nation, as it is assumed to advantage Labor. winners in government and losing candidates from the opposition is just .03. The difference in probability of support for this between candidates on the far left and far right is (.26). Politicians' preferences for electoral institutions thus appear to be shaped by the independent effects of self-interest and by the equally important but less systematic effects of values and ideology. The former are perhaps easily understood given existing theory, but the latter are important enough to suggest that existing theory may inflate the dominant role of electoral self-interest on politicians' preferences for institutions.

\section{Discussion}

Plainly, there is a difference between attitudes towards change that politicians reveal in academic surveys and change itself. Attitudes, however, are a necessary precursor to change, and we can thus learn more about the conditions that shape actual change from these responses.

When we look at politicians' attitudes about proposals to change their electoral institutions, we find significant effects of personal electoral self-interest, evaluations of how democracy is working, post-materialist values, and ideology. The effect of self-interest is partly a confirmation of a received wisdom that is not often put to the direct test. This confirmation, however, is tempered by the acknowledgement that self-interest is not the entire explanation of how politicians view electoral institutions. Self-interest is a major determinant of attitudes but other factors also play a role. Values and ideology play an important but not quite as predictable a role in structuring elite responses to institutions. Ideological pressures are 
seen as left-wingers and right-wingers offer competing views of an ideal political process.

We also find an important difference between personal and partisan electoral interests. A candidate's personal electoral self-interest has a systematic effect on attitudes about changing political institutions that remains significant even after we account for their evaluations of how democracy is working, their values and ideology. Candidates who win, from government and opposition parties, appear more similar in their views about change than candidates who lose. This result is consistent with the party cartel theory that assumes politicians in office share an incentive to limit competition with those who are out of office.

These findings beg an important question: if values and ideology have effects that are as substantively large as electoral self-interest (as we find here), then why do electoral institutions remain so stable in established democracies? That is, why don't these institutions change more often when candidates with different values and ideology defeat incumbent politicians? The case of the German Greens offers some insight to this question. Despite being winners (i.e., affiliated with the party in government and even elected to the legislature), Green respondents elected to the Bundestag remain committed to institutional changes that advance the role "outsiders" would have in the political process (GPCA Platform 2004). German Greens support referendum and initiative use in astonishingly large proportions. However, when other things (such as ideology and party status) are held constant, our models still predict that a candidate who wins an election is significantly less likely to support direct democracy. So, just as German Greens moderated their positions on NATO and Kosovo once in government, these results suggest that a candidate's perspectives on electoral institutions may also change once they win. Indeed, German Green commitment to radical democratic practices such as rotation in office (term limits) was strained, if not weakened, in order for Joschka Fischer to reach the post of Foreign Minister (Klotzsch et al. 1998).

This example is by no means unique: Britain's Labour party lost enthusiasm for PR after they won in 1997. Australian opposition candidates similarly forgot their interest in direct democracy once in power (Williams and Chin 2000), and Republicans in the United States gave up their push for term limits on Congress (part of their "Contract with America") soon after taking control of the U.S. House of Representatives in 1994. These real-world examples, combined with our results, provide evidence consistent with the argument that personal electoral self-interest is a powerful determinant of politicians' attitudes towards institutions.

What are the wider consequences of these results? Over the longer term politicians appear likely to become strongly committed to the rules that made them winners. As obvious as this may sound, it offers an explanation for a puzzle. Rules and institutions are supposed to limit cycling over outcomes by making, for example, some changes difficult or by making some actors more consequential. However, if institutions are seen as a solution to cycling over preferences then, as Riker (1986) asks, what if preferences over institutions-and hence institutions themselvescycle? It is a question that pushes an explanation of political stability back a stage further: institutional forces alone may not explain stability if preferences over institutions also cycle as politicians make changing the rules part of the game.

Our answer to that question is that winners become invested in, or at least attached to, the rules that made them winners. Winners are committed to the status quo-even if they are very recent winners and even if they are in the opposition. This is a somewhat different interpretation of why institutions represent "congealed preferences" than offered by Riker, to whom we owe the phrase. Winners are reluctant to change rules that made them winners and-hencewe can expect to see only very slow changes in those sorts of rules. We know that the people and parties who form governments change relatively frequently. But we also know that the electoral institutions that structure how these governments come into place are quite static. Much of the stability of election rules may reflect that being in parliament (winning) quickly unites actors who differ in terms of policy preferences and ideology at least on one dimension. Winning election and serving in parliament leads to a unifying electoral self-interest that dampens support for institutional change among those who may have embraced change when on the outside looking in.

\section{Acknowledgments}

Authorship is equal; names are listed alphabetically. An earlier version of this paper was presented at the 2004 Annual Conference of the Western Political Science Association Meeting, Portland, OR, and the 2005 Southern Political Science Association Meeting, New Orleans, LA. The authors would like to thank Rachel Gibson and Ian McAllister of Australian National University and Hermann Schmitt and 
Andreas M. Wüst of the University of Mannheim for replicating our questions and giving us access to their data. Responsibility for errors and interpretations of all data used in this paper rests with the authors.

\section{Manuscript submitted 10 February 2005}

Manuscript accepted for publication 26 September 2005

\section{References}

$\rightarrow$ Anderson, Christopher, and Christine Guillory. 1997. "Political Institutions and Satisfaction with Democracy: A CrossNational Analysis of Consensus and Majoritarian Systems." American Political Science Review 91 (1): 66-81.

Andrews, Josephine, and Robert Jackman. 2005. "Strategic Fools: Electoral Rule Choice Under Extreme Uncertainty." Electoral Studies 24 (1): 65-84.

$\rightarrow$ Angus, H.F. 1952. "Note on the British Columbia Elections in June 1952." Western Political Quarterly 5 (4): 585-91.

$\rightarrow$ Bawn, Kathleen. 1993. "The Logic of Institutional Preferences: German Electoral Law as a Social Choice Outcome." American Journal of Political Science 37 (4): 965-89.

Benoit, Kenneth. 2004. "Models of Electoral System Change." Electoral Studies 23 (3): 363-89.

Birch, Sarah, Frances Millard, Marina Popescu, and Kieran Williams. 2003. Embodying Democracy; Electoral System Design in Post-Communist Europe. New York: Palgrave Macmillan.

Blais, Andre, and Louis Massicotte. 1997. "Electoral Formulas: A Macroscopic Perspective." European Journal of Political Research 32 (1): 107-29.

$\rightarrow$ Boix, Carles. 1999. "Setting the Rules of the Game: The Choice of Electoral Systems in Advanced Democracies." American Political Science Review 93 (3): 609-24.

$\rightarrow$ Bowler, Shaun, Todd Donovan, and Jeffrey A. Karp. 2002. "When Might Institutions Change? Elite Support for Direct Democracy in Three Nations." Political Research Quarterly 55 (4): 731-54.

Converse, Philip. E. 1964. "The Nature of Belief Systems in Mass Publics." In Ideology and Discontent, ed. David E. Apter. New York: Free Press, pp. 206-61.

Cox, Gary. 1997. Making Votes Count: Strategic Coordination in the World's Electoral Systems. New York: Cambridge University Press.

Dalton, Russell. 2002. Citizen Politics. New York: Chatham House.

Dalton, Russell, Wilhelm Burklin, and Andrew Drummond. 2001. "Public Opinion and Direct Democracy." Journal of Democracy 12 (4): 141-53.

$\rightarrow$ Dunleavy, Patrick, and Helen Margetts. 1995. "Understanding the Dynamics of Electoral Reform." International Political Science Review 16 (1): 9-29.

Geddes, Barbara. 1996. “Initiation of New Democratic Institutions in Eastern Europe and Latin America." In Institutional Design in New Democracies: Eastern Europe and Latin America, eds. Arend Lijphart and Carlos Waisman. Boulder: Westview Press, pp. 15-41.

GPCA Platform. 2004. http://www.cagreens.org/platform/ democrac.htm. Accessed Feb 26, 2004.
Grofman, Bernard. 1990. Political Gerrymandering and the Courts. New York. Agathon Press.

Gunther, Richard. 1989. "Electoral Laws, Party Systems and Elites: The Case of Spain." American Political Science Review 83 (3): 835-58.

Hibbing, John R., and Elizabeth Theiss-Morse. 2002. Stealth Democracy: Americans' Beliefs about How Government Should Work. New York: Cambridge University Press.

Inglehart, Ronald. 1977. Silent Revolution. Princeton: Princeton University Press.

Karp, Jeffrey, and Peter Aimer. 2002. "Direct Democracy on Trial: The Citizens-Initiated Referendums." In Proportional Representation on Trial: The 1999 New Zealand General Election and the Fate of MMP, eds. Jack Vowles, Peter Aimer, Jeffrey Karp, Susan Banducci, Raymond Miller, and Ann Sullivan. Auckland: Auckland University Press, pp. 146-59.

Katz, Richard S., and Peter Mair. 1995. "Changing Models of Party Organization and Party Democracy: The Emergence of Cartel Parties." Party Politics 1 (1): 5-28.

Klotzsch, Lilian, Klaus Könemann, Jorg Wischermann, and Bodo Zeuner. 1998. "What Happens to Green Principles in Electoral and Parliamentary Politics?" In The German Greens: Paradox between Movement and Party, eds. Margit Mayer and John Ely. Philadelphia: Temple University Press, pp. 158-97.

Liberal Democrats. 2000. Reforming Governance in the UK Policies for Constitutional Reform. Policy Paper 40. Liberal Democrats web site http://www.libdems.org.uk/documents/policies/ Policy_Papers/REFORM.pdf Accessed February 27, 2004.

Lijphart, Arend. 1992. "Democratization and Constitutional Choices in Czecho-Slovakia, Hungary and Poland 1989-91." Journal of Theoretical Politics 4 (2): 207-23.

Lijphart, Arend. 1999. Patterns of Democracy: Government Forms and Performance in Thirty-Six Countries. New Haven: Yale University Press.

Mackerras, Malcolm, and Ian McAllister. 1999. "Compulsory Voting, Party Stability and Electoral Advantage in Australia." Electoral Studies 18 (2): 217-33.

$\rightarrow$ Miller, Nicholas. 1983. "Pluralism and Social Choice." American Political Science Review 77: 734-47.

Muller, Wolfgang C., and Kaare Strom. 1999. Policy Office or Votes: How Political Parties in Western Europe Make Hard Decisions. New York: Cambridge University Press.

$\rightarrow$ Norris, Pippa, 1995. "The Politics of Election Reform." International Political Science Review 16 (1): 3-9.

$\rightarrow$ Peffley, Mark, and Jonathan Hurwitz. 1985. "A Hierarchical Model of Attitude Constraint." American Journal of Political Science 29 (4): 871-90.

Przeworski, Adam. 1991. Democracy and the Market. New York: Cambridge University Press.

Rahat, Gideon. 2004. "The Study of the Politics of Electoral Reform in the 1990s: Theoretical and Methodological Lessons." Comparative Politics 36 (4): 239-52.

$\rightarrow$ Riker, William. 1980. "Implications from the Study of Disequilibrium of Majority Rule for the Study of Institutions." American Political Science Review 74 (2): 432-46.

Riker, William. 1986. The Art of Political Manipulation. New Haven: Yale University Press.

Rokkan, Stein. 1970. Citizens, Elections, Parties: Approaches to the Comparative Study of the Processes of Development. New York: McKay.

Sakamoto, Takayuki. 1999. "Explaining Electoral Reform: Japan versus Italy and New Zealand." Party Politics 5 (4): 419-38. 
Shepsle, Kenneth. 2001. "A Comment on Institutional Change." Journal of Theoretical Politics 13: 321-25.

Shvetsova, Olga. 2003. "Endogenous Selection of Institutions and their Exogenous Effects." Constitutional Political Economy 14 (3): 191-212.

Tsebelis, George. 1990. Nested Games: Rational Choice in Comparative Politics. Berkeley: University of California Press.

Tyler, Tom R. 1990. Why People Obey the Law. New Haven: Yale University Press.

Williams, George, and Geraldine Chin. 2000. "The Failure of Citizens' Initiated Referenda Proposals in Australia: New Directions for Popular Participation?" Australian Journal of Political Science 27 (1): 41-45.
$\mathrm{Xu}$, Jun, and J. Scott Long. Forthcoming. "Confidence Intervals for Predicted Outcomes in Regression Models for Categorical Outcomes." The Stata Journal.

Shaun Bowler is professor and chair of political science, University of California, Riverside, Riverside, CA 92521. Todd Donovan is professor of political science, Western Washington University, Bellingham, WA 98225. Jeffrey A. Karp is assistant professor of political science, Texas Tech University, Lubbock, TX 79409-1015. He is also senior research fellow, Institute for Governance Studies, University of Twente, The Netherlands. 